Novel sponsor makes a debut in European technology research

Verona

THE European Institute of Technology (EIT), an eight-month-old consortium of multinational corporations, made an intriguing debut in biotechnology research funding at its second symposium, in Verona, last week. An enigma to both public and private sectors as well as raising eyebrows at the European Commission, EIT nevertheless received more than 850 research proposals from universities in response to an April call for tenders. Even though it had less than 1 million ECU (European currency units; 1 ECU = $£ 0.83$ ) to hand out, EIT whet appetites with the prospect of $250,000 \mathrm{ECU}$ per year, for three years, and the unusual offer to pay short-listed applicants 15,000 ECU to prepare a more detailed proposal.

EIT is the brain-child of its president, John Marcum, whose tour as director for science, technology and industry of the Organisation for Economic Cooperation and Development (OECD) in 1984-87 ruffled a few diplomatic feathers. The institute has three principal aims. First, it hopes to foster partnerships between industry and university in the fields of biotechnology, information and materials technology by providing grants for precompetitive research considered likely to yield patentable innovations. Second, EIT promises its industrial members access to a network of leading public-sector researchers. Finally, the institute hopes to offer training courses in technology management through workshops, 30-day courses and a one-year master's programme.

The idea arose after a round-table of European industrialists abandoned a plan to create a bricks-and-mortar European technology institute. Instead, EIT was set up simply as an office in the Paris business neighbourhood, La Defence, with a staff of less than ten and constituted as a nonprofit-making educational establishment.

So far, five corporations have paid the $200,000-\mathrm{ECU}$ annual subscription to join the consortium: EniChem, IBM Europe, Montedison, Philips and AT\&T, giving EIT a start-up capital of 1 million ECU. With such small resources, explained Marcum, EIT needs to be highly selective, both in terms of the research areas it will sponsor and in the quality of specific projects. "We are an élitist organization", he says, adding that many industryuniversity collaborations fail because 'second-rate' researchers are chosen from each sector. To solicit interest from leading university researchers - and to create the promised networks - EIT decided to offer the prospect of large grants. But only between five and ten of the 850 proposals will finally be approved and at rates of an average $100,000 \mathrm{ECU}$ per year for three years, making the 250,000 ECU advertised grants look to some like an ingenuous but effective bootstrapping ploy.

Marcum is nevertheless confident that EIT's initiative will pay dividends. Any patents resulting from research it has sponsored will belong to EIT and royalties will be shared in proportion to the sums invested. "We will have to be tough about this", said Marcum. "In the past, universities undercharged, now they're overcharging." Having collaborated in generating the new ideas, sponsoring companies will be free to compete to develop marketable products, or seek partnerships through EUREKA, Europe's market-led programme to get competitive advanced technology ideas into production. Meanwhile, EIT expects to make enough from royalties eventually to be self-sufficient, at least in its education venture.

Superficially similar to EUREKA, EIT has taken care to avoid overlap, by including EC, national government and public-sector representatives on its three Technology Expert Panels. Klaus Draxler, present chairman of EUREKA's group of national programme coordinators (NPCs), who was in Verona to find out more about EIT for the Community, con- firmed that the two organisations could be mutually beneficial. EIT essentially scours university research groups for budding new concepts (top-down), while EUREKA aims to bring existing ideas, without limitations of domain, to fruition (bottom-up).

Draxler was more concerned that EIT's research programme would clash with the Community's own pre-competitive advanced technology projects, such as ESPRIT, RACE and BRITE. There is also a risk that EIT's education and training programme could conflict with COMETT, which aims to provide Europe-wide training for innovation and development, application and management of new technologies. But he thinks EIT's notion of networks is a good idea. "It could help everyone, including EUREKA. We don't know how fruitful collaborations really come about. It's a matter of contacts. Companies don't have university contacts and so they don't know whom they can work with."

In order to have any lasting influence, EIT will now have to strengthen its industrial membership. Whether the enthusiastic response to EIT's first advertisement is repeated or not is now less important in this respect, as it will have flushed out most of the best ideas and identified who should be in the 'networks'. Meanwhile, 16 of the original applicants (six of them from the United Kingdom) have received small grants to have a crack at the major awards, to be given out next March.

Peter Coles

\section{Finding a punishment to fit the crime}

\section{Berkeley}

A FORMER chancellor and professor of British history at the University of California, Santa Barbara, who found the campus chancellor's house too unpleasant to occupy, may soon be rubbing elbows with illiterate criminals, teaching them to read as part of his punishment for embezzlement of university funds.

Robert Huttenback became chancellor of the Santa Barbara campus in 1977. In 1979, he and his family moved out of the house provided them by the university, giving as reasons the lack of a neighbourhood environment, a high noise level and the "institutional nature" of the house. The family moved to an expensive Santa Barbara neighbourhood, and received an annual housing allowance from the university for mortgage, maintenance, insurance and property taxes. But Huttenback and his wife also spent university money on home improvements such as a new kitchen and house furnishings.

Huttenback resigned as chancellor in July 1986 after a university investigation concluded that he had inappropriately spent $\$ 174,000$ on his home. The investiga- tion found no wilful intent to deceive the university, and the matter was considered settled by Huttenback's resignation and agreement to repay the money.

But a separate state investigation last year concluded that the inappropriate expenditures totalled $\$ 271,000$, and Huttenback and his wife were charged with embezzlement and evasion of taxes. They were convicted in July 1988; and in September they were fined a total of $\$ 70,300$ and Huttenback was ordered to perform 1,000 hours of community service, developing a programme to teach functionally illiterate criminals to read, as part of the Santa Barbara city adult literacy programme.

Huttenback is said to have claimed that he believed his expenditures were justified, because his home was used for university functions. He has been suspended from his position as full professor of British history, while the university reviews the case under the faculty code of conduct and decides what action to take. The first University of California chancellor to be convicted of a felony, Huttenback has filed an appeal.
Marcia Barinaga 